The following values were studied : $\mathrm{pH}$, water retention ability, coloring, transformation yield, amount of residual nitrite, and distribution of sodium chloride in the finished product.

As a general rule, the series effect plays an important role. Sex effect is limited to $\mathrm{pH}$ in the thigh muscle, undressed weight, skin weight, fat covering weight, and brining gain. The female pig ham has the highest yield. Breed effect is usually highly significant, except for the amount of sodium chloride in five sampling sites, lard weight, coloration index, and water retention ability in fresh ham. Values obtained for crossed pigs are intermediary between those of the parental brecds.

Progressive regression analysis shows that $\mathrm{pH}$ combined with water retention ability constitutes a good indication of the transformation yield of Paris ham.

Piétrain ham has the best yield as regards transformation into Paris ham. To this advantage must be added the fact that there is a higher percentage of ham in the Piétrain carcass. The over-all superiority of this breed over the Large White is expressed by I $\mathrm{kg}$ more of Paris ham per pig slaughtered at $95 \mathrm{~kg}$, that of the crossed pig being about $900 \mathrm{~g}$.

\title{
PREMIERS RÉSULTATS D'UNE EXPÉRIENCE DE SÉLECTION RÉALISÉE DANS UN CENTRE D'INSÉMinAtion ARTIFICIELLE PORCINE
}

\author{
L. OLLIVIER \\ Laboratoìre de Génétique quantitative et appliquée, \\ Centre national de Recherches zootechniques, I. N. R. A., \\ 78 - Jouy-en-Josas
}

\section{RÉSUMÉ}

Les résultats de cette expérience ont été présentés par L. Ollivier à la Commission de Génétique, Journées d'Études de la F. E. Z., août 1970, Gödollö (Hongrie) et un résumé a été publié dans les Annales de Génétique et de Sélection animale ( $\mathrm{I} 97 \mathrm{r}$, vol. $3, \mathrm{n}^{\circ} \mathrm{I}$ ) p. 107.

\section{SUMMARY}

FIRST DATA OF THE SELECTION EXPERIMENT REALIZED

IN AN ARTIFICIAL INSEMINATION CENTRE, FOR PIGS

The results of this experiment were reported by L. OlLIvier at the Commission on Animal Genetics, F. E. Z., August 1970, Gödollö (Hungaria) and a summary has been published in Annales de Génétique et de Sélection Animale (1971, vol. 3, no I) p. Iо7. 